\title{
MS104.P01
}

\section{Characterization of the 12th century archaeological ceramics of Jbel Igîlîz}

\author{
Driss Zakaria ${ }^{1}$, M'Barek Belaaroussi $^{1}$, Abdallah Fili ${ }^{2}$, Mohamed Ouadia ${ }^{3}$, Boumediene Tanouti ${ }^{1}$ \\ ${ }^{1}$ Laboratoire de Physico-Chimie des Matériaux, Département de Chimie, Université Chouaib Doukkali, El Jadida, Morocco, \\ ${ }^{2}$ Laboratoire Le Maroc et les pays méditerranéens, Département d'Histoire, Université Chouaib Doukkali, El Jadida, Morocco, \\ ${ }^{3}$ Laboratoire des Géosciences et Techniques de I'Environnement, Département de Géologie, Université Chouaïb Doukkali, El Jadida, \\ Morocco \\ E-mail: zdriss@hotmail.com
}

Jbel Igîliz is a mountain known by the medieval texts for having sheltered the place of birth of Ibn Tûmart, founder of the Almohad Empire (1120-1269) which extended to the Maghreb and a large part of the Iberian Peninsula. It is therefore a site of great historical importance for the Middle Ages of the Maghreb. Situated in the Moroccan Anti-Atlas (fig), the Igîîz site was located in 2004 by Fili, A. and Van Staëvel, J.-P.1. The excavations that have been undertaken since 2009 have shown that it offers a particularly relevant anchor to initiate a historical and archaeological study of the evolution of the countryside of the Presaharian Maghreb during the medieval period. The present study is devoted to the archaeometric analysis of the many ceramic pieces updated on the site (49 pieces) whose main use seems to be domestic (fig). In a first classification, the samples were separated into glazed and non-glazed ceramics and analyzed by thin-polarized optical microscopy and X-ray diffraction. According to the mineralogy, showing the abundance of very fine quartz grains, one can claim the exploitation of silts, marls and clays. The presence, in considerable quantity, of organic matter can be related to residues, rich in organic matter, left behind after the use of the object of which they are part. While for non-glazed parts, given the abundance of calcite and fragments of marine shells, the raw material used may be of aquatic origin (probably marls). The scarcity of organic matter can be explained by the low frequency (few organic residues) of the use of the object these parts. The variable color of the carbonate crystals reveals a fluctuation in the degree of humidity, in relation to changes in climatic conditions, at the site. Structural analysis by X-ray diffraction for pulverulent sample or clay fraction on oriented and treated slides (normal, calcined, ethylene glycol) allowed an accurate identification of the phases present in each type of parts. The non-glazed pieces are composed of quartz, calcite, albite, phengite, microcline and dolomite with a variable rate. Same analyzes carried out on the local natural clay of the Jbel of Igîîz, actually used by potters in this region, showed the same mineralogical composition as the non-glazed pieces in addition to the presence of a clay type kaolinite which can highlight the local production of the archaeological pieces non-glazed and the use of calcinations stage at a temperature above $500^{\circ} \mathrm{C}$ in the process of their manufacture at that era. However, the glazed ceramic, which have finer structure and probably calcinated at higher temperature, are composed of diopside, quartz, muscovite gehlinite. This composition can be compared to that reported by Vieira Ferreira et al.2 for updated ceramics in a palace of the Islamic period (8th-13th century) located in Silves, Portugal. This can testify to the proven exchanges that prevailed in the Middle Ages.

[1] Fili, A. et al. 2006, Al-Qantata, XXXVII, 153-194.

[2] Vieira Ferreira, L.F. et al. Journal of Archaeological Science, 2016, Reports 6, 182-189

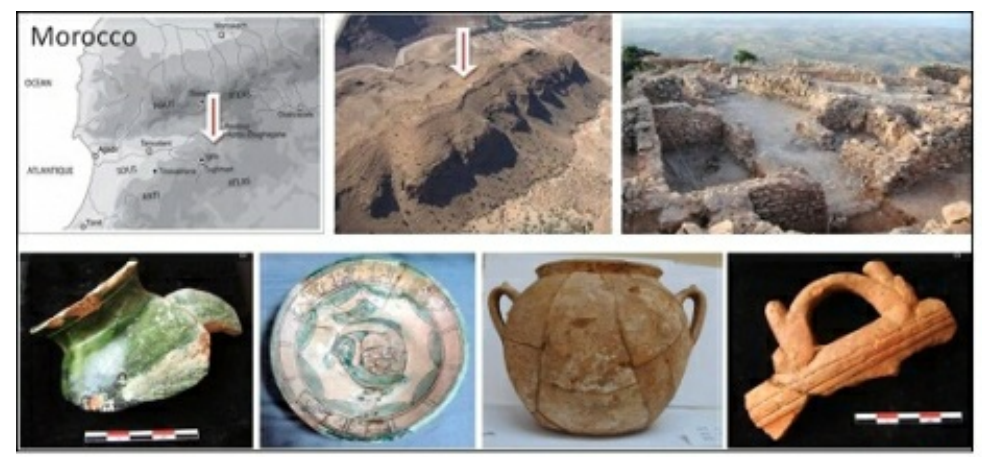

Keywords: Characterization, archaeological ceramics, Jbel Igîlîz 